\title{
ASIAN INDIAN MUSLIM NEGOTIATING FOR IDENTITY IN THE POST 'SEPTEMBER ELEVENTH' AS DEPICTED IN THE FILM MY NAME IS KHAN
}

\author{
Fajriani \\ Alumni of American Studies Graduate Program \\ Universitas Gadjah Mada
}

\begin{abstract}
This article is an attempt to examine the problem of Muslim identity and how they negotiate their identity as Muslim whereas they have to face anti Muslim racism by Americans. The film has the theme of racism in the context of Muslim racial profiling. Therefore to accomplish the objectives, it applies Kant's theory called as "races of mankind" that is, people are distinguishable according to their inherited physical attributes. This term illustrated the racialized of religion in the context of physical attributes related to labeling of Muslim racial profiling and stereotypes as terrorist. Since "September Eleventh", Muslim is suspected as terrorist and has to be responsible for the tragedy. The interesting fact found in the analysis of the Asian Indian Muslim identity in the United States America post "September Eleventh" as depicted in the film is that, the Muslim Americans community was particularly impacted by the attacks and has had to face the growing Islamophobia including discrimination and prejudice, racial hatred, as well as violence. Rising Islamophobia and the negative reaction of American society to "September Eleventh" have led to changing definitions of the good multicultural society in the United States of America. Therefore, to decrease the impact of Islamophobia, Asian Indian Muslim Americans undergo the process of negotiation for their identity as Muslim through the way such as assertiveness in faith, showing the truth of Islam and participate in social activity. Accordingly, Americans Muslim can reduce the suspicions of their identity until Americans do not assume them as threat even less as enemy but rather as human being that have right to be appreciated because of their humanity and not because of their identity as Muslim.
\end{abstract}

Key words: Negotiation, Asian Indian Muslim identity, September Eleventh, Muslim racial profiling.

\section{INTRODUCTION}

Diversity is the thing that God has given in the world of America. This diversity also can create the anxiety or phobia that is difficult to be omitted by American society. This kind of anxiety can be like the anxiety to foreigner or to other people who are distinct in some way of race, caste, ethnic or religion. The most visual difference in multiethnic society in the United States of America is usually the issue of race, whereas the largest number of crime referring to racial hatred is sometimes followed by the crime motivated by religion. It is related to the case of Islam, when the tragedy of the crash "September Eleventh" happened in the U.S. as Islam is then connected to the action of terrorism. Americans have negative stereotypes to Muslim. Muslim becomes the victim of misconception in which they experience racial hatred referring to their racial profiling as Muslim that identically have the way of their dressing and wearing the headscarf. This way of life which constitutes to the profile of the Muslim becomes the reason why people assume some of the Muslim as terrorist who are, in this case, they are responsible for the tragedy. In the western world, history is marked simply by $\mathrm{BC}$ and $\mathrm{AD}$. But now, there is a third distinction " $9 / 11$ " (MNIK, 01:03:00) Related to this issue, it is still very much in reformed Muslim identity especially when they face the tragedy of "September Eleventh" in which they have to experience 
some actions of Islamophobia as from of the backlash from Americans who perceived lose everything in their life and its real consequences for Muslims living in the United States of America. Islamophobia can be defined as the action addressed to Muslim in the form of discrimination, prejudice, racial hatred, and violence rooted in misinformed and stereotyped representations of Islam and its adherents (Ghazali, 2008, p.18). It seems very ironic because not every Muslim is a terrorist. But then, Muslim America has to pay the cost over the death of humanity in the United States of America related to the tragedy.

Furthermore, this article aims to reveal the factors that contribute toward Asian Indian Muslim's uncomfortable experience in the post "September Eleventh" as depicted in the film My Name Is Khan as well as to find out how Asian Indian Muslims negotiate their identity in the post "September Eleventh" as depicted in the film My Name Is Khan.

In doing this research, library research is used in order to collect the appropriate data which are needed in analyzing the topic. The main data are taken from the film My Name is Khan. The supporting data are taken from other sources such as some critical books, essays, journal, articles, and some data from the internet (international network) related to the context of Asian Indian Muslims identity and Muslim Americans in the United States of America. All those data are compiled together as supporting data.

To gain the needed data, the movie is watched repeatedly to observe the striking scenes, the portrayal of the characters, and the development of the characterization and many other aspects that appropriate to the discussion of this research. It is done particularly on the conditions in American society in the post "September
Eleventh" that make the Asian Indian Muslims feel uncomfortable because of being targeted as terrorist in the United States of America and how they create the harmonic relationship with Americans through the process of negotiation for their identity as Muslim in the United States of America as depicted in My Name Is Khan.

\section{DISCRIMINATION AND PREJUDICE}

In this research, discrimination and prejudice against Muslim Americans viewed that the reality of an entire race of Muslims related to their identity, portraying them as terrorists and treating them as the "others" after the "September Eleventh" incident. In the film $M y$ Name is Khan reflects the dangerous for Muslims become the victims of misconception as terrorist. Muslims experienced in uncomfortable and unhappy life since the tragedy crash "September Eleventh".

In the film, after the "September Eleventh", discrimination and prejudice to Muslims are found in the very beginning of scene whereby Khan (the main character of the film) continues to endure long waits at airports, where he are often asked for questioning. It tells the condition in which Khan whose identity is Muslim, he is detained at airports by American airport security when he took a plane and he is being interviewed regarding to his identity. $\mathrm{He}$ is fumbling with pebbles in his hand and starts reciting a Surah in Arabic (a verse from Holy Quran). A lady in front of him stares at him suspiciously. Next he is being asked by an officer to come with him.

Would you come with me, sir? Hands in front, hands behind your head Behind your head and turn around open your mouth

Anything on the watch-list, George No flags. He's clean. Okay Mr. Khan, we are done here. You can go. 
But why are you going to Washington $D C$ ?

I'm going to meet the President of the United States.

Why is that? Is he a friend of yours?

Oh, no, no, no. He is not a friend. No,

no, no. I have something to say to him

Oh yeh? Yes

Well, tell the President something from

me too then

Okay, okay

Tell him I said, howdy.

But I have my own message to give to him first

Oh yeah? What is that? You know where

Osama is? Oh no, no, no, no. No, this is not my message. No, no, no What is your message, Mr. Khan?

I have to say to him. My name is Khan and I'm not a terrorist

(MNIK, 07:36)

From the quotation above, he has to face some investigations as he is accused of a terrorist who has relation with Osama bin Laden. Osama bin laden following the tragedy of "September Eleventh", is accused of the agent responsible for the crash attack of World Trade Centre. Osama is Muslim known by Americans as the leader of the Islamic fundamentalist, Al-Qaeda. Al Qaeda by American is known as the tenet of Jihad or the holy war that allows violent act and murder. In the story of Khan, the airport officials suspect Khan having connection with Osama. Then, Khan reveals their misunderstanding and whispers in his suffering of Asperger Syndrome that he wants to meet the President of the United States to tell him that "My name is Khan, and I am not a terrorist." The airport officials ask Khan about his message to president and look at him with sympathy and confusion but are unable to answer his statement. The snickering officers only see that his name is Khan, he is a Muslim, and he becomes the suspect. Muslims are treated through the heavy scrutiny that has to be done to fight Islamic terror. Furthermore, to raise the psychological effect on Khan, in terms of the high security he experiences, he is checked for hours, and thereby he loses his flights. Nevertheless, the incident of the arrest of Khan is clearly to show his Muslim identity, to bring down his fear, just the opposite of the airport officials who do not have tolerance with Muslim.

For Khan, after the tragedy of "September Eleventh", it encouraged him to struggle hard to maintain as well as to show his identity as a Muslim. It is more difficult to be a Muslim in the United States. Most Americans feel prejudice and anxiety to Muslim. The experience of Khan related to the profiling of Muslim in airports by airport security officers cause the emergence of misconception among Americans toward Muslims, in this case of Khan, that tends to treat as the enemy of the state, the enemy of the United State of America so that those people had acted suspiciously to him because of his name.

Race as recognized by visual and eternal characteristics, whereas religion is identified by a body of ideas and practices. Hence, racist and religious crime is particularly hurt the victims because they are being targeted solely because of their personal identity, their actual or perceived racial or ethnic origin or their actual or perceived belief or faith.

In the film My Name is Khan the bigotry and racial hatred in the United States culminate in the senseless killing of a young Indian boy Sam or Sameer, who is beaten to death by youths in the football ground, in part due to the adopting of his stepfather's name, Khan. This murderous of Khan's son is very painful for Khan. Related to this issue, the film portrays the life of Muslim who experiences the discrimination, especially 
in refer to the character of Khan. Since the tragedy of "September Eleventh", he experiences suspicion because of his identity as Muslim. Because of his religious belief, he is treated as a person unpleasantly. Besides, his family also becomes the victim of misunderstanding because he marries a Hindu woman who has one child in her previous marriage and unexpectedly his stepson died because of adopting his name. Consequently, the wife of Khan, Mandira, the mother of his stepson, feels miserable for the tragedy. It can be seen as follows

Sam, my baby. We killed him.

It's time for dinner. Doctors say that post traumatic disorder causes people to ignore their health.

Both of us killed him.

You need to take care of your health.

Just shut up, shut up. Are you listening

to what I am saying?

We killed him (MNIK, 01:24:32)

It is my entire fault. If I hadn't married you, all this wouldn't have happened. I though you loved me so much, loved Sam so much. What difference would it make if his name is changed? What difference would it make if a 'Khan' was added to his name? But I was wrong. It makes a difference. It does make a difference. I should never have married a Muslim man! If Sam had been a Rathod (Hindu) he would have been alive today. He was a Khan, so, he died. (MNIK, 01:25:14).

Following the events of "September Eleventh", Khan and Muslims in general as well as those who marry with Muslims begin to face a number of difficulties and their life has change drastically. Following a tragedy, for a while, they have to separate because Mandira's son has been killed. The tragedy that sacrifices his stepson, the murder of Sam, makes Khan and Mandira separate for a while. When this effect reaches Khan, indirectly, makes him uncomfortable and injures him because it is so bad that it dangers his marriage. What his autistic mind instructs him to save his marriage is by having a journey meeting the President of the United States of America. In order to solve it, Khan begins a long journey across the United States living up to the demand of his wife. He goes against the odds, does what a normal mind would feel insensible and tries to save his happiness. He travels across America attempting to meet the President of the United States to deliver a memorable message as direction of his wife, "My name is Khan and I am not a terrorist. He wants to explain that not all Muslims are terrorists.

He died because of you. Because of your surname! I don't even want to see you. Whenever I see you, I remember Sam's wounds. I can't do this anymore. I'm leaving you, Khan When should you be back?

You know Banville? It has a population of 30.000 and each of those 30.000 people hates you. Tell all of them that you are not a terrorist. Why only them? Tell every person in America. Can you do that? Can you? No, you can't. Why don't you tell the President of United States then? Mr. President, my name is Khan and I'm not a terrorist. So, he can tell all these people that my Sam was not the terrorist son of a terrorist father. He was just a baby. When you have done that, please comeback.

I'm just a mother whose son has been killed (MNIK, 01:34:08) 
From the quotation above it is clear that Khan experiences extreme personal hardships due to his religion. These hardships culminate in the tragic death of his teenage son Sam, beaten to death in the school playing field by boys of Caucasian origin (older student in Sam's school). In his son grief, Sameer's mother, Mandira blames her husband Khan, accusing him of the fact that if she and her son had not taken the name of Khan, her son would not be dead. She then tells Khan sarcastically that the only way he can atone for this stigma of being a Khan and, by implication a Muslim, is to meet the United States President and to tell him that: "My Name is Khan and I am not a Terrorist." The message for President becomes the requirement from Mandira to Khan in order that Khan can reunite together with her.

The tragedy of 'September Eleventh' presents two combination identities namely terrorist and noncitizen that constitute national identity. This national identity creates racialist Muslim identity in the sense of race in the United States of America post terrorist attack that cause racial profiling to Muslim. This is serious social issues of stereotyping and profiling of Muslim with sensitivity whereas Khan as conveyed in the film My Name is Khan appears to have been profiled because he has a common Muslim last name Khan. Furthermore, Chris Barker (National identity: 197) proposed that the nation-state, nationalism and national identity as collective forms of organization and identification are not 'naturally' occurring phenomena but contingent historical-cultural formations. The nation-state is a political concept which refers to an administrative apparatus deemed to have sovereignty over a specific space or territory within the nation state system. National identity is a form of imaginative identification with the symbols and discourses of the nation state. Thus, nations are not simply political formations but systems of cultural representation through which national identity is continually reproduced as discursive action. The nation-state as a political apparatus and a symbolic form has a temporal dimension in that political structures endure and change while the symbolic and discursive dimensions of national identity narrates and creates the idea of origins, continuity and tradition. Related to the case of Khan, the reason of Mandira asks Khan to meet Presidents because President constitutes the symbol of national identity.

Since "September Eleventh", Muslims in the United States of America are living in fear. In the film My Name is Khan, Rizwan Khan, a Muslim man has been put into jail without any specific reason. The black September is the decade of fear in accordance with surveillance and deportation. Khan experiences a trauma for no fault he has committed. Khan is almost incapables to handle how American world works that put him as the other. He accepts the scrutiny concern accusation as terrorist. He becomes the target by the FBI (Federal Bureau of Investigation) that leads to his fear and grief. He was called a terrorist and tortured mercilessly.

A moving portrait of a Muslim in the alienating landscape of a post "September Eleventh" in the United States, Khan attempts to keep his family together in the wake of international and personal tragedies by willing to accept the inhuman attack as an accusation from FBI's nationwide that hunts for terror suspects to be arrested, incarcerated and tortured. Khan is sent to prison where he is mentally and physically tortured.

This place is stranger. There are no windows to any room and the bathrooms do not have a door. And the toilet has lock. My eyes burn and I feel sleepy too. At times, it's very hot here. At other times, it is very cold. I told them I would repair air conditioner but they won't let me. They do 
not even tell me the time so that I can pray. That's why every time I feel scared. I bow and pray (MNIK, 01:58:00)

From the quotation above shows that the tortures are visibly depicted in the film My Name is Khan and are apparently based on the true life accounts of innocent victims by FBI who have been illegally arrested and committed to prison like Khan, for no other reason just because of his religious faith background. This event gives the facts that Khan as Muslim in the United Stated of America is illegally abducted, detained and tortured. Nevertheless, the government did not find evidence linking the agent to the "September Eleventh" attack related to the terrorist movement.

\section{THE PROCESS OF MUSLIMS NEGOTIATING FOR IDENTITY POST "SEPTEMBER ELEVENTH"}

Negotiation concerns on the series of Muslim effort to create the solidarity among religious diversity post "September Eleventh". Through negotiation, Muslim will be received by American society inch by inch and it will support the new social reality to create tolerance and comprehension among religious interfaith in the United States of America. American religion is like such negotiation among religious groups and American society to understand as well as tolerance each other. Then, the process of negotiation for Muslims identity as conveyed in the film My Name is Khan including 1) Assertiveness in faith; 2) Participate in social activity; and 3) Showing the truth of Islam. Thus, below are the discussions.

In the film My Name is Khan it shows the Muslim man who remains consistent to his Muslim identity. He is Rizwan Khan. The fact that Khan is a pious Muslim is also a form of assertiveness in his faith because there is nothing wrong for Khan with being an outwardly devout Muslim. To be a pious Muslim in the midst of conflict as the effect of the tragedy black September is very significant way to face the prejudice and other kinds of Islamophobia.

In one of the scene of the film, the mother of Khan advises him a message that there are no fixed labels such as Hindu and Muslim, but only good and bad people, Khan freely practices his religion with equal love and respect for all other races and creeds, only differentiating between what is in the hearts and minds of people, not to what religion they profess, or to what race, culture and nationality they belong.

Hadith says that the Almighty does not judge by color or creed but by actions and deeds. If that is the truth then Rizvan Khan by the sheer force of his actions has elevated the entire of humanity in the eyes of God (MNIK, 02:50:00)

It is shown in a Hadith reflected in the film $M y$ Name is Khan, Khan understands the fundamentalist in practicing their knowledge about Qur'an and Hadith. Therefore, this is to show the fact there is no mistake in his faith about his comprehension of Qur'an and hadith. This action is on the contrary of becoming the essential thing in maintaining and negotiating for his Muslim identity among American society in the post "September Eleventh". This is also the assertiveness that Islam is not a barbaric and violent religion.

The tragedy of "September Eleventh" brings experience to some extent and creates the conditions for the religious sentiment including Khan. It can be seen in the following quotation

I'm sure Allah is happy that Sameer is with him in heaven (MNIK, 01:42:57) 
I'm Imran and this is Sajida

It's time for the bus to leave. This is Prayer time.

Prayer time? Now? Here? You should pray depending upon the place and the people around

No, no, no. Prayer should never depend upon the place and the people. It should depend only on your belief (MNIK, $01: 35: 41)$

I have reached Los Angeles now. The President is coming visit the college campus here. I have reached three days before him so that I do not miss him this time around. I am going to pray that Allah wills it so too (MNIK, 01:46:22).

Rizwan Khan, a Muslim man and a simple man who leads a simple life, is devoted to his family and religion and who is accused of being a terrorist in the United States of America. He overcomes the obstacles facing against unjust world after "September Eleventh". He has created a certain pride in being a devoted and strong Muslim which is shown in the film. He always persists recalling the name of Allah in his heart anytime and wherever he is. He prays five times a day, as most Muslims do, Khan uses phrases from the Koran in his daily conversation and believes that justice will prevail both in this world and the afterlife for those who uphold the existence of God (Allah), Prophet Mohammad and Islam.

Considering that in the following the tragedy of black September, it is harder to be a Muslim in the United States, American Muslims have to recovery the bad image as terrorist that addressed to them. The accusations as terrorist label for Muslim are unclear and unreasonable because the terror actions constitute the activity which do not respect to the boundaries of religion, race and geography. Islam constitutes inclusive religion, love the peaceful, and respect to dissimilarity.

In accordance with this issue, one of the scenes in the film My Name is Khan shows how Khan wants to purify the misconception among other Muslims about their wrong perception concerning to their comprehension about the meaning of the religious story of the Quran. Partly Muslims in the United States of America sometimes have the negative views and does not understand well about the interpretation of Quran. The film also portrays a Muslim man, Dr. Faisal Rehman who thinks the terror action as the backlash of the injured Muslims. The action of Dr. Faisal Rehman who preaches about the revenge to the people who have tortured Muslim before and the aftermath of "September Eleventh" is a dramatic. Below what Dr. Faisal Rehman has said as conveyed in the film

Listen, listen brothers. We are digressing. I have said it before. I have no problem with Christians or the Jews. In fact, I have no problems with our Hindu brothers too. I treat a lot of Hindu patients in St. Benedict's hospital. I get angry only when this same grace is not reciprocated towards us Muslims.

My blood boils when Israeli Jews massacre our Palestinian brothers or when Hindu in India cut our women and children to pieces with their swords. That's when my bloods. Doesn't your blood boil? Answer me, answer me.

It does, it does. 
So, do something! I Dr. Faisal Rehman, take an oath that I'm ready. Are you all ready? Are you?

Yes, we are.

Mighty Allah had even asked Ibrahim to sacrifice his son. And without asking a single question, Ibrahim agreed to sacrifice him. It's our turn today. It's our duty to let our blood flow for the cause of Islam. This is what Allah demands! This is what Islam demands! (MNIK, 02:30:00)

From the quotation above, Dr. Faisal Rehman wants to conduct the backlash for people who hold the injustice treatment toward Muslims by delivering the logic reasons why Muslim have to revenge. He convinces his adherent to revenge by delivering the story of the agreement of Prophet Ibrahim to sacrifice his son. He considers that murder is allowed in Islam so that the revenge or backlash will be permitted by Allah. He is unaware or willfully ignorant of the Quran that surmounts universal non-violence. He does not understand that Islam preaching values of peace, love, and tolerance. Therefore, Khan receives the misinterpreting statement by laying out his understanding of what the Prophet really said and meant to them.

My Ammi has told the story about Saint Ibrahim. Saint Ibrahim did not doubt the compassion of the lord. The story is an example of his immense strong faith and belief. And that's the reason why despite being incited by a stranger repeatedly. Saint Ibrahim did not waver from his path of righteousness. He did not listen to the stranger. He was sure Allah would never allow the blood of his progeny to be shed. And he was right. The mighty Allah saved Ismail's life.
This story shows that the path of Allah is that of love. Not of hatred and war. Allah's path is that of compassion. That's why his loved ones are called "blessed by the compassionate!" (MNIK, 01:51:00)

Through the story above, the conviction of Khan to the rightness of the story is appropriate with his mother's comprehension about how the tenet of Islam is. Islam has five pillars or basic foundations to act. Acting correctly and sincerely on these foundations will transform a Muslim's life into the line of the Creator. Faithful practice of these duties inspires him to work towards the establishment of justice, equality and righteousness in society, and the eradication of injustice, falsehood and evil. Hate cannot be countered with hate. Khan believes on that tenet.

Furthermore, in the film My Name is Khan describes that it is difficult for American Muslim to show the truth of their religion because many Americans considers that there is connection between Islam and terror action in the following tragedy of "September Eleventh". For Khan, the terror action is useless and extreme practices that only create more and more hatred. Therefore, it happens because many people in the United States do not understand well about Islam and consider that the tenet of Islam as "Jihad" (the holy war) in related to terrorism whereas Islam is anti terrorism and Muslims society is very tolerant. Therefore, Khan then read one of the verses in Quran that:

In chapter five, verse 32 of the Quran, Allah has decreed that the death of one innocent is equal to the death of humanity (MNIK, 01:01:00).

Many people realize that there is no the actions of terror as broad as the tragedy of September 
Eleventh. Asian Indian Muslims and Muslim in general cannot live safely because of it and they are accused as a terrorist. Related to this issue, in the Quran explicitly condemns the action that causes the die of human being. It is portrayed in Quran that whosoever killed a human being for other than man slaughter or corruption, it shall be as if he had killed all mankind (QS 5:32). In other occasion Quran asserts that punishment to whomever that engender the emergence of disturbance or turmoil in the earth; it is the same as the punishment to them who give battle to God (Allah) and His Prophet.

Generally, Muslim Americans have to recognize that they live in plural country in order that they are necessary to maintain their Muslim identity. Pluralism constitutes challenges for the possibility of constructing a strong and positive religious identity in the context of pluralism. In the pluralistic country Muslim in the United States could more understanding of history, religious traditions and tolerance in the case of religious interfaith. In the film My Name is Khan, the existence of Muslim as American has been recognized. Therefore, they have to show their loyalty to their nation and state as American. They have dual identity as Muslim and as Americans. Nevertheless, as American they have to loyal to their country by truly implemented their right and obligation citizenship and in the other side remain perform their religious faith.

In the film My Name is Khan, Rizwan Khan shows his social participation by giving a help hand to the Georgia town people namely to Mama Jenny (a black American) who suffering in a flood. It can be seen in the following quotation

Mama Jenny, Mama Jenny, I have to go to her. I have come to Wilhemina, Georgia.
Mama Jenny and funny hair Joel are in trouble (full on by hurricane molly) (MNIK, 02:10:00)

Khan hears that hurricane has hit Georgia and he immediately helps Mama Jenny. Later, many people find Khan in Georgia and join him and then they subsequently rescue Mama Jenny and the folks there. For the first time, he doesn't experience judgment and rejection by new people in a rural shantytown in Georgia. Sadly, the town residents embody crude, outdated and painful stereotypes of African Americans, right down to their names ("Mama Jenny" and "Funny Haired Joel"). The media airs Khan's story and this is seen by everyone. Khan gives support and power to Mama Jenny to remember the miserable time in the past of the colored people in the South and references to the civil rights movement via the theme song "We Shall Overcome" (song from 1960s). The film describes the purpose in educating and enlightening Westerners in a very subtle way through the exploration of the themes and the images to the United States and the West. The action of Khan shows how he participates in society to gain harmonic relation among religious interfaith.

\section{CONCLUSION}

The crash of "September Eleventh" has changed the course of the history and has affected many communities including Muslim. The Muslim Americans community has been particularly impacted by the attacks and has had to face the growing Islamophobia, including discrimination and prejudice, racial hatred, as well as violence. Rising Islamophobia and the negative reaction of American society to "September Eleventh" have led to the difficult position of Asian Indian Muslims because of their profiling as Muslim. 
Therefore, to decrease the impact of Islamophobia, Asian Indian Muslim Americans undergo the process of negotiation for their identity as Muslim through the ways such as assertiveness in faith, showing the truth of Islam and participating in social activity. The film $M y$ Name is Khan shows the character of Khan who gives information that has the quality of enlightenment, awareness and understanding to American society about Islam with his way he brings back and constructs the positive image of Islam in the midst of Americans that generally keep Islamophobia on Asian Indian Muslims in the post "September Eleventh". Khan thinks more open to other Americans or get his act together with other American society. To define his role as Muslim Americans and keep moving forward, he has to attempts to improve the image of Islam wherein Islam is an inclusive religion (part of a whole or part of a larger society), love peace, and admiring to disparity. Khan portrays the struggle of Muslim as the way to negotiate his identity as Muslim in the United States of America in the post "September Eleventh" as conveyed in the film My Name is Khan.

\section{REFERENCES}

Barker, Chris. (2000). Cultural Studies Theory and Practice. Sage Publications: London, Thousand Oaks, New Delhi

Ghazali, A. S. (2008). Islam \& Muslims in the Post-9/11 America. Eagle Enterprises, Modesto, CA. April.
Hellmich, C. (2005). Al-Qaeda: Terrorists, Hypocrites, Fundamentalists? The View from Within. Third World Quarterly, Vol. 26, No. 1. Taylor \& Francis, Ltd

Imam Muhni. D. (2003). Methods of American Studies.

Iqbal, Z. (2010). Islamophobia or Islamophobias: Towards Developing a Process Model. Islamic Studies 49:1, pp. 81-101

McDowell, T. (1948). American Studies. Minnea polis: The University of Minnesota Press.

Reed, T. V. (2001). Theory and method in American Cultural Studies: A Bibliogra phic Essay. Retrieved from http://www .wsu.ed/ amerstu/tm/tmhome.html.

Rose, P. I. (1968). The Subject is Race. London Toronto: Oxford University Press.

Rouse, C. M. (2004). Engaged Surrender: African American Women and Islam. Berkeley: University of California Press.

William, R. B. (1998). Religions of Immigrants from India and Pakistan: New Threads in the American Tapestry. Cambridge: Cambridge University Press.

Wise, G. (1979). Paradigm Dramas' in American Studies: A Cultural and Institutional of the Movement. American Quarterly. Summer [1979], No.22, p.295-337. 